\title{
Perbedaan Kadar Adiponektin, Asimetrik Dimetilarginin Plasma, dan Respons Vasodilatasi Arteri Brakialis antara Dewasa Muda dengan Riwayat Bayi Berat Lahir Rendah dan Normal
}

\author{
Augustine Purnomowati, ${ }^{1}$ Sri Hartini K.S. Kariadi, ${ }^{1}$ Tri Hanggono Achmad, ${ }^{2}$ Johanes C. Mose, ${ }^{3}$ \\ Budhi Setianto ${ }^{4}$ \\ ${ }^{1}$ Departemen Ilmu Penyakit Dalam, ${ }^{2}$ Departemen Biokimia, ${ }^{3}$ Departemen Obstetri dan Ginekologi, \\ ${ }^{4}$ Departemen Kardiologi dan Kedokteran Vaskular Fakultas Kedokteran Universitas Padjadjaran \\ Rumah Sakit Dr. Hasan Sadikin Bandung
}

\begin{abstract}
Abstrak
Adiponektin mempunyai efek antiaterogenik, antiinflamasi, sensitizer insulin, dan berperan penting dalam mengatur pertumbuhan janin. Hipoadiponektinemia dapat menyebabkan disfungsi endotel. Risiko penyakit kardiovaskular meningkat pada subjek dengan riwayat bayi berat lahir rendah (BBLR). Penelitian ini bertujuan menganalisis perbedaan kadar adiponektin, asimetrik dimetilarginin (ADMA) plasma dan respons vasodilatasi arteri brakialis melalui tes flow mediated brachial artery (FMBA) antara dewasa muda dengan riwayat BBLR dan bayi berat lahir normal (BBLN), serta korelasi kadar adiponektin dengan fungsi endotel pada BBLR. Penelitian kohor retrospektif dilakukan periode November 2009-Januari 2010 berasal dari Growth Study Cohort Tanjungsari Kabupaten Sumedang. Sebanyak 134 subjek dipilih secara simple random, terdiri atas 67 BBLR dan 67 BBLN yang karakteristik umumnya sama. Analisis multivariat melalui Hotelling's trace menunjukkan FMBA, kadar ADMA, dan adiponektin berbeda bermakna $(\mathrm{p}<0,001)$ antara BBLR dan BBLN. Analisis simultaneous confidence interval menunjukkan kadar adiponektin plasma dan FMBA bermakna lebih rendah $(\mathrm{p}=0,015$ dan $\mathrm{p}<0,001)$ pada BBLR dibandingkan dengan BBLN. Korelasi tidak bermakna antara kadar adiponektin dan ADMA $(r=-0,16 ; p=0,176)$ dan $\operatorname{FMBA}(r=0,13 ; \mathrm{p}=0,281)$ BBLR. Kecil peran adiponektin pada disfungsi endotel, mungkin variabel lain berperan, seperti tumor necrosis factor $\alpha$. Simpulan, terdapat perbedaan kadar adiponektin plasma dan FMBA antara dewasa muda dengan riwayat BBLR dan BBLN, tetapi kecil peran adiponektin pada disfungsi endotel dewasa muda dengan riwayat BBLR. [MKB. 2012;44(1):1-6].
\end{abstract}

Kata kunci: Adiponektin, asimetrik dimetilarginin, BBLR, tes flow mediated brachial artery

\section{Differences of Plasma Adiponectine, Asymmetric Dimethylarginine and Brachial Artery Vasodilatation Response in Young Adult with Low and Normal Birth Weight History}

\begin{abstract}
Beside an anti-atherosclerotic, anti-inflammation effect, and a sensitizer insulin, adiponectin also play an important role in fetal growth. Hypoadiponectinemia may lead to endothelial dysfunction. Low birth weight (LBW) has increase risk of cardiovascular disease. The aim of this study was to analyze the differences of plasma adiponectin, asymmetric dimethylarginine (ADMA) level and vasodilatation response of brachial artery by doing flow mediated brachial artery (FMBA) test between young adults with LBW and normal birth weight (NBW), and the role of adiponectin level in endothelial function of the LBW. This was a retrospective cohort study during November 2009January 2010, 134 subjects were randomly selected from the Growth Study Cohort of Tanjungsari Sumedang. They consisted of 67 LBW and 67 NBW young adults, with similar basic characteristics. A multivariate analysis via Hotelling's trace showed that there was a significant difference $(\mathrm{p}<0.001)$ for FMBA, ADMA, and adiponectin level, but simultaneous confidence interval measurements indicated that the rate of FMBA and the level of plasma adiponectin were significantly lower ( $\mathrm{p}<0.001, \mathrm{p}=0.015$, respectively) in LBW compared to NBW. The correlation between adiponectin and ADMA level $(r=-0.16, p=0.176)$, and FMBA $(r=0.13, p=0.281)$ in LBW were not significant, suggesting a small role of plasma adiponectin in endothelial dysfunction of young adults with LBW, other variables could play a role such as tumor necrosis factor $\alpha$. In conclusions, the level of plasma adiponectin and FMBA are different between LBW and NBW, but the role of adiponectin may be small in endothelial dysfunction in young adults with LBW. [MKB. 2012;44(1):1-6].
\end{abstract}

Key words: Adiponectin, asymmetric dimethylarginine, flow mediated brachial artery, LBW test

Korespondensi: Dr. Augustine Purnomowati, dr., Sp.PD, Sp.JP(K), Departemen Ilmu Penyakit Dalam Fakultas Kedokteran Universitas Padjadjaran-Rumah Sakit Dr. Hasan Sadikin, Bandung jalan Pasteur 38 Bandung, telepon (022) 2049026, mobile0811206357,e-mail purnomokunto@yahoo.com 


\section{Pendahuluan}

Nutrisi buruk pada saat janin akan menyebabkan bayi berat lahir rendah ( $<2.500$ gram). Pada bayi berat lahir rendah (BBLR) terjadi perubahan struktur, fungsi, metabolisme, dan endokrin, serta disfungsi endotel yang menetap, melewati masa kanak-kanak dan memasuki kehidupan dewasa. Keadaan tersebut berkaitan dengan kejadian penyakit kardiovaskular di kemudian hari. ${ }^{1,2}$

Adiponektin merupakan adipositokin yang berperan pada pertumbuhan janin. ${ }^{3,4}$ Salah satu mekanisme yang diduga berperan dalam kejadian penyakit kardiovaskular yaitu kadar adiponektin plasma yang rendah. Hipoadiponektinemia secara langsung dapat menyebabkan disfungsi endotel yang merupakan awal proses aterosklerosis. ${ }^{5}$ Tindakan preventif primordial perlu dilakukan agar terhindar dari paparan faktor risiko. ${ }^{6}$ Tindakan primordial tersebut yaitu melakukan pemeriksaan fungsi endotel sedini-dininya. Petanda dini gangguan fungsi endotel berupa gangguan jalur enzim nitric oxide synthase (NOS) atau sintesis vasodilator nitrogen oksida (NO). ${ }^{7}$ Secara laboratoris terdapatnya NO dalam darah sulit dideteksi mengingat waktu paruh NO yang pendek hanya beberapa detik, maka secara tidak langsung NO dapat diperiksa dengan flow mediated brachial artery (FMBA) $)^{8,9}$ dan kadar asimetrik dimetilarginin (ADMA) yaitu suatu inhibitor endogen enzim NOS yang bekerja kompetitif dengan ${ }_{1}$-arginin. $^{10}$

Barker, ${ }^{1}$ peneliti pertama yang berpendapat bahwa BBLR meningkatkan risiko kejadian penyakit kardiovaskular. Penelitian Barker telah direplikasi dan dipublikasi oleh peneliti Amerika Serikat serta beberapa negara lain dengan hasil bervariasi. ${ }^{11,12}$ Mengingat prevalensi BBLR masih tinggi terutama di negara berkembang seperti Asia Afrika $^{13}$ (Indonesia sekitar 11,5\% ${ }^{14}$ ) dan BBLR meningkatkan kejadian penyakit kardiovaskular di kemudian hari, maka peran adiponektin plasma terhadap fungsi endotel sangat penting.

Tujuan penelitian ini untuk menganalisis perbedaan kadar adiponektin, FMBA, dan ADMA rata-rata antara kelompok BBLR dan bayi berat lahir normal (BBLN), serta korelasi kadar adiponektin dengan parameter fungsi endotel (FMBA dan kadar ADMA plasma). Penelitian ini diharapkan dapat mengembangkan tindakan preventif primordial penyakit kardiovaskular dan diagnostik disfungsi endotel sedini-dininya.

\section{Metode}

Penelitian dilakukan sejak awal bulan November 2009 sampai dengan awal bulan Januari 2010.
Subjek penelitian diambil dari penelitian Growth Study yaitu penelitian kohor Tanjungsari (Risk Approach Strategy by Traditional Birth Attendants) yang telah melakukan pengumpulan data mengenai berat dan panjang lahir serta lingkar kepala bayi yang lahir periode tahun 1988-1990; kemudian pertumbuhan dan perjalanan klinis bayi tersebut diikuti. Mereka yang bertahan hidup dan berusia 12-15 tahun (tahun 2004) diikutsertakan dalam penelitian mengenai profil lemak darah. ${ }^{15}$ Saat ini, mereka telah berusia 19-21 tahun dan diikutsertakan pada penelitian epidemiologi klinik dengan rancangan kohor retrospektif.

Berat lahir (BBLR dan BBLN) merupakan variabel bebas, sedangkan variabel efek (terikat) berskala rasio yaitu adiponektin dan ADMA plasma serta FMBA.

Kriteria inklusi: dewasa muda berusia 19-21 tahun dengan riwayat BBLR dan BBLN, pernah di-random dan diikutsertakan dalam penelitian faktor risiko sebelumnya yang dipilih secara simple random. Kriteria eksklusi: mereka yang menderita penyakit ginjal kronik, penyakit hati, gagal jantung, serta minum obat-obatan steroid, antidiabetika, nitrat, dan multivitamin.

Pada penelitian ini mengingat ada 1 parameter yang belum tersedia yaitu $\sigma^{2}$ (varians) ADMA, maka ukuran sampel ditentukan oleh pengujian korelasi dengan menggunakan tabel yang tersedia. ${ }^{16}$ Besar sampel masing-masing kelompok (BBLR dan BBLN) untuk uji satu arah sebanyak 67, bila korelasi terkecil yang dinyatakan bermakna adalah $\rho=0,30$; nilai $\alpha=0,05$; dan power $(1-\beta)=0,80$.

Uji statistik dilakukan dengan 2 tahap untuk menentukan perbedaan variabel terikat rata-rata antara kedua kelompok. Tahap pertama, ketiga variabel terikat diuji menggunakan multivariate statistical analysis for two independent samples. Pada tahap kedua untuk menentukan variabel rata-rata yang berbeda dengan menggunakan simultaneous confidence interval. Uji korelasi Pearson digunakan bila data berdistribusi normal, sedangkan bila distribusi tidak normal dipakai uji korelasi Spearman. Data dasar subjek dinyatakan dalam nilai rata-rata dan simpangan baku (SB). Analisis statistik menggunakan perangkat lunak SPSS Windows versi 13.0.

Penelitian ini telah mendapat persetujuan dari Komite Etik Penelitian Kesehatan Fakultas Kedokteran Unpad/Rumah Sakit Dr. Hasan Sadikin Bandung.

\section{Hasil}

Sebanyak 67 dari 245 orang BBLR dan 67 dari 516 orang BBLN yang telah di-random sebelumnya, memenuhi kriteria inklusi dan eksklusi penelitian. 
Tabel 1 Data Dasar Subjek Dewasa Muda dengan Riwayat BBLR dan BBLN

\begin{tabular}{lcc}
\hline \multicolumn{1}{c}{ Parameter } & $\begin{array}{c}\text { BBLR } \\
(\mathbf{n = 6 7 )}\end{array}$ & $\begin{array}{c}\text { BBLN } \\
(\mathbf{n}=\mathbf{6 7}=\end{array}$ \\
\hline Usia, tahun & $20,30(0,57)$ & $20,24(0,58)$ \\
Laki-laki, \% & 52,2 & 56,7 \\
Tekanan darah sistol, mmHg & $117(10)$ & $119(10)$ \\
Tekanan darah diastol, mmHg & $76(6)$ & $78(7)$ \\
Hemoglobin, g/dL & $15,0(1,6)$ & $15,3(1,3)$ \\
Kadar gula darah puasa, mg/dL & $86,0(6,7)$ & $84,8(8,7)$ \\
Kadar kolesterol total, mg/dL & $158,5(26,7)$ & $161,3(30,1)$ \\
Kadar trigliserida, mg/dL & $84,4(40,4)$ & $95,10(51,4)$ \\
HDL-C, mg/dL & $44,4(8,8)$ & $43,5(8,5)$ \\
LDL-C, mg/dL & $100,1(23,6)$ & $101,8(24,6)$ \\
SGOT, unit/liter & $21,6(6,5)$ & $21,5(7,0)$ \\
SGPT, unit/liter & $21,5(13,6)$ & $20,4(10,9)$ \\
Ureum, mg/dL & $19,1(5,4)$ & $18,3(4,5)$ \\
Kreatinin, mg/dL & $0,68(0,14)$ & $0,71(0,16)$ \\
Indeks massa tubuh, kg/m ${ }^{2}$ & $20,1(3,3)$ & $20,7(3,2)$ \\
Perokok: laki-laki, \% & 88,6 & 89,5 \\
\hline
\end{tabular}

Tabel 2 Distribusi Kadar Adiponektin Plasma, ADMA Plasma, dan Respons Vasodilatasi Arteri Brakialis pada Subjek Dewasa Muda dengan Riwayat BBLR dan BBLN

\begin{tabular}{lcccc}
\hline \multirow{2}{*}{ Variabel } & \multicolumn{2}{c}{ BBLR } & \multicolumn{2}{c}{ BBLN } \\
\cline { 2 - 5 } & $\mathbf{p}$ & Distribusi & $\mathbf{p}$ & Distribusi \\
\hline Kadar adiponektin plasma & 0,104 & Normal & 0,766 & Normal \\
Kadar ADMA plasma & 0,921 & Normal & 0,739 & Normal \\
Respons vasodilatasi arteri brakialis (tes FMBA) & 0,435 & Normal & 0,319 & Normal \\
\hline
\end{tabular}

Lilliefors significance correction

Data dasar subjek kedua kelompok tampak sepadan (Tabel 1).

Riwayat penggunaan obat antidiabetika, antihipertensi, nitrat, vasoaktif, dan multivitamin serta obat lainnya tidak ditemukan pada kedua kelompok.

Hasil uji normalitas data dengan menggunakan lilliefors significance correction menunjukkan bahwa respons vasodilatasi arteria brakialis (melalui tes FMBA), kadar ADMA, dan adiponektin plasma berdistribusi normal dengan $\mathrm{p}>0,05$ (Tabel 2).
Berdasarkan uji multivariate analysis for two independent samples, ketiga variabel menunjukkan perbedaan yang sangat bermakna $(\mathrm{p}<0,001)$. Uji selanjutnya dengan simultaneous confidence interval ditemukan variat rata-rata yang berbeda antara BBLR dan BBLN, yaitu kadar adiponektin plasma $(p=0,015)$ dan respons vasodilatasi arteri brakialis $(\mathrm{p}<0,001)$. Kadar ADMA plasma rata-rata antara BBLR dibandingkan dengan BBLN tidak ada perbedaan yang bermakna $(\mathrm{p}=0,669)$ (Tabel 3$)$.

Uji korelasi Pearson menunjukkan korelasi

Tabel 3 Perbedaan Kadar Adiponektin Plasma, Kadar ADMA Plasma, dan FMBA Rata-rata antara Subjek Dewasa Muda BBLR dan BBLN

\begin{tabular}{lrrrr}
\hline \multicolumn{1}{c}{ Variabel } & $\begin{array}{c}\text { BBLR } \\
(\mathbf{n}=67)\end{array}$ & $\begin{array}{c}\text { BBLN } \\
(\mathbf{n = 6 7 )}\end{array}$ & $\mathbf{p}$ & $\mathbf{9 5 \%}$ IK \\
\hline $\begin{array}{l}\text { Keseluruhan (adiponektin, ADMA, dan } \\
\text { respons vasodilatasi)* }\end{array}$ & & & $<0,001^{*}$ \\
Kadar adiponektin plasma, $\mu \mathrm{g} / \mathrm{mL}$ & $4,07(1,29)$ & $4,64(1,61)$ & $0,015^{* *}$ & $-1,083-(-0,082)^{* *}$ \\
Kadar ADMA plasma, $\mu \mathrm{Mol} / \mathrm{L}$ & $0,71(0,15)$ & $0,69(0,15)$ & $0,669^{* *}$ & $-0,041-(0,064)^{* *}$ \\
Respons vasodilatasi arteri brakialis, \% & $8,40(3,06)$ & $11,66(3,63)$ & $<0,001^{* *}$ & $-4,409-(-2,114)^{* *}$ \\
Diameter awal arteri brakialis, cm & $3,35(0,47)$ & $3,33(0,42)$ & $0,758^{* *}$ & \\
\hline
\end{tabular}


Tabel 4 Korelasi Kadar Adiponektin Plasma dengan Kadar ADMA dan Respons Vasodilatasi (RV) Arteri Brakialis pada Subjek Dewasa Muda dengan Riwayat BBLR

\begin{tabular}{lrc}
\hline \multirow{2}{*}{ Korelasi } & \multicolumn{2}{c}{ BBLR } \\
\cline { 2 - 3 } & \multicolumn{1}{c}{$\mathbf{~}$} & $\mathbf{p}$ \\
\hline Adiponektin dengan ADMA & $-0,16$ & 0,176 \\
Adiponektin dengan RV & 0,13 & 0,281 \\
\hline
\end{tabular}

Uji korelasi Pearson

negatif yang sangat lemah tetapi secara statistik tidak bermakna kadar adiponektin dengan ADMA plasma pada kelompok subjek BBLR ( $\mathrm{r}=-0,16$; $\mathrm{p}=0,176)$. Korelasi antara kadar adiponektin dan respons vasodilatasi arteri brakialis menunjukkan korelasi positif lemah yang secara statistik tidak bermakna pada BBLR $(\mathrm{r}=0,13 ; \mathrm{p}=0,281)$. Data ini menunjukkan kecilnya peranan adiponektin terhadap ADMA dan respons vasodilatasi arteri brakialis (Tabel 4).

Pada penelitian ini juga didapatkan kelompok BBLR secara bermakna berpeluang lebih besar untuk mempunyai kadar adiponektin plasma rendah dan respons vasodilatasi arteri brakialis atau hasil tes FMBA rendah dibandingkan dengan kelompok BBLN (Tabel 5). Berdasarkan kurva receiving operating characteristic (ROC) didapatkan nilai cut-off kadar adiponektin plasma rendah, yaitu $\leq 4,13 \mathrm{ug} / \mathrm{mL}$ dan respons vasodilatasi arteri brakialis rendah $\leq 9,5 \%$.

\section{Pembahasan}

Pada penelitian ini kadar adiponektin plasma lebih rendah secara bermakna pada BBLR dibandingkan dengan BBLN. Hasil yang sama pernah dilaporkan Cianfarani dkk., ${ }^{17}$ namun dilakukan pada subjek kecil untuk masa kehamilan (KMK). Penyebab kadar adiponektin rendah karena obesitas dapat disingkirkan mengingat kedua kelompok (BBLR dan BBLN) mempunyai IMT yang sepadan sekitar $20 \mathrm{~kg} / \mathrm{m}^{2}$. Kemungkinan penyebab kadar adiponektin rendah akibat malfungsi jaringan lemak seperti yang dikemukakan Barker ${ }^{1}$ dan faktor genetik seperti polimorfisme nukleotida tunggal (single nucleotide polymorphysms) 276 pada gen adiponektin dan memerlukan penelitian lebih lanjut. ${ }^{5}$

Adiponektin meningkatkan produksi NO melalui stimulasi enzim eNOS, oleh karena kadar adiponektin plasma lebih rendah, maka produksi NO pun akan lebih rendah pada subjek kelompok BBLR dibandingkan dengan BBLN. Terdapatnya NO dapat dideteksi dengan memakai tes FMBA yang menunjukkan hasil lebih rendah pada kelompok BBLR. Penelitian ini sesuai dengan hasil penelitian Leeson dkk. ${ }^{18}$ yang mendapatkan respons vasodilatasi lebih rendah pada kelompok BBLR daripada BBLN, tanpa meneliti apa yang menyebabkannya, namun diduga akibat perubahan fungsi vaskular karena gangguan pertumbuhan in utero. Fungsi vaskular atau endotel bermacammacam, namun gangguan fungsi endotel terdini yaitu gangguan keseimbangan vasodilatasi dan vasokonstriksi. ${ }^{7}$

Secara klinis disfungsi endotel lebih banyak terdapat pada kelompok subjek dewasa muda dengan riwayat BBLR dibandingkan dengan BBLN, tampak sebagai respons vasodilatasi arteri brakialis (FMBA) yang rendah yaitu $8,40 \%$ dibandingkan dengan $11,66 \%$. Padahal diameter awal arteribrakialis kedua kelompok secara statistik tidak berbeda bermakna, namun memberikan respons vasodilatasi yang berbeda bermakna antara kedua kelompok. Disfungsi endotel ini seharusnya didukung oleh pemeriksaan kadar NO, namun mengingat waktu paruh NO yang pendek, maka secara tidak langsung melalui pemeriksaan

Tabel 5 Risiko Relatif BBLR untuk Mempunyai Kadar Adiponektin Plasma Rendah, Kadar ADMA Tinggi, dan Respons Vasodilatasi Arteri Brakialis Rendah

\begin{tabular}{|c|c|c|c|c|}
\hline Variabel & $\begin{array}{l}\text { BBLR } \\
(\mathrm{n}=67)\end{array}$ & $\begin{array}{l}\text { BBLN } \\
(n=67)\end{array}$ & Nilai $p$ & RR (95\% IK) \\
\hline Adiponektin (ug/ML) & & & 0,016 & $1,53(1,07-2,18$ \\
\hline$\leq 4,13$ & $41(60 \%)$ & $27(40 \%)$ & & \\
\hline$>4,13$ & $26(39 \%)$ & $40(61 \%)$ & & \\
\hline RV (\%) & & & $<0,001$ & $2,94(1,91-4,53$ \\
\hline$<9,5$ & $50(75 \%)$ & $17(25 \%)$ & & \\
\hline$>9,5$ & $17(25 \%)$ & $50(75 \%)$ & & \\
\hline ADMA (mMol/L) & & & 0,216 & $1,32(0,89-1,96$ \\
\hline$\geq 0,89$ & $12(63 \%)$ & $7(37 \%)$ & & \\
\hline$<0,89$ & $55(48 \%)$ & $60(52 \%)$ & & \\
\hline
\end{tabular}

Keterangan: uji chi-kuadrat, $\mathrm{RV}=$ respons vasodilatasi, $\mathrm{RR}=$ risiko relatif $\mathrm{BBLR}$ 
kadar ADMA yang tampak lebih tinggi tetapi tidak bermakna pada kelompok BBLR. Kadar ADMA yang tinggi dapat disebabkan oleh 1) peningkatan metilasi protein oleh protein-arginin $\mathrm{N}$ metil transferase tipe 1 (PMRT-1), 2) gangguan fungsi ginjal dan hati, 3) proteolisis dan pelepasan metilarginin, dan 4) degradasi oleh dimetilarginin dimetil aminohidrolase tipe 2 (DDAH-II). ${ }^{19}$

Kadar ADMA dipengaruhi oleh shear stress, ${ }^{20}$ namun melalui tes FMBA kedua kelompok baik BBLR maupun BBLN mendapat perlakuan atau shear stress yang sama (bukan fisiologis), sehingga kemungkinan kadar ADMA yang tinggi karena perlakuan shear stress dapat diabaikan.

Kemungkinan gangguan fungsi ginjal dan hati sebagai penyebab ADMA yang cenderung tinggi pada BBLR dibandingkan dengan BBLN dapat diabaikan dengan kriteria eksklusi penelitian. Karakteristik umum kelompok BBLR tampak sepadan dengan kelompok BBLN (Tabel 1), sehingga dapat diabaikan kemungkinan kadar ADMA yang tinggi akibat peningkatan metilasi protein atau proteolisis, yang terjadi bersamaan dengan hambatan metabolisme ADMA melalui degradasi enzim DDAH-II akibat stres oksidatif.

Pada penelitian ini satu-satunya yang dapat menerangkan mengapa kadar ADMA agak tinggi pada kelompok BBLR daripada BBLN yaitu kadar adiponektin plasma. Eid dkk. ${ }^{21}$ tahun 2007 melaporkan hasil penelitian kultur sel endotel tali pusat manusia dan menemukan akumulasi ADMA yang dipengaruhi oleh adiponektin dan insulin.

Terdapatnya korelasi positif lemah yang tidak bermakna antara kadar adiponektin plasma dan respons vasodilatasi arteri brakialis pada tes FMBA, dan korelasi negatif lemah yang tidak bermakna antara kadar adiponektin dan ADMA plasma, menunjukkan terdapat faktor-faktor lain di tingkat selular yang mempengaruhi fungsi endotel subjek dewasa muda dengan riwayat BBLR, namun bukan faktor risiko konvensional bila melihat data dasar subjek yang sepadan antara kelompok BBLR dan BBLN. Kenyataan ini ditunjang oleh perbedaan kemaknaan kadar adiponektin plasma dan respons vasodilatasi arteri brakialis antara kelompok BBLR dan BBLN (Tabel 2). Faktor lain yang perlu diteliti lebih lanjut pada subjek BBLR adalah vasokonstriktor seperti endotelin-1, angiotensin II, tromboksan $\mathrm{A}_{2}$, prostagladin $\mathrm{H}_{2}$, dan tumor necrosis factor $\alpha$ (TNF $\alpha$ ) mengingat selain dapat menghambat produksi adiponektin, ${ }^{5} \mathrm{TNF} \alpha$ juga dapat menginduksi akumulasi ADMA. ${ }^{21}$

Secara teknis kemungkinan lain penyebab lemahnya korelasi adiponektin dengan FMBA dan ADMA oleh karena ukuran sampel yang kecil, seharusnya untuk uji korelasi pada penelitian ini diperlukan 2.799 subjek. ${ }^{16}$ Kelemahan lain penelitian ini yaitu tercampurnya intrauterine growth restriction (IUGR) dan preterm di dalam kelompok BBLR.

Simpulan, terdapat perbedaan kadar adiponektin plasma dan respons vasodilatasi arteri brakialis pada kelompok subjek dewasa muda dengan riwayat BBLR dibandingkan dengan BBLN, namun kecil peranan adiponektin pada disfungsi endotel subjek dewasa muda dengan riwayat BBLR.

\section{Daftar Pustaka}

1. Barker DJP. The developmental origins of adult disease. J Am Coll Nutr. 2004;23:588S-95.

2. Norman M, Martin H. Preterm birth attenuates association between low birth weight and endothelial dysfunction. Circulation. 2003; 108:996-1001.

3. Kajantie E, Hytinantti T, Hovi P, Anderson S. Cord plasma adiponectin: a 20-fold rise between 24 weeks gestation and term. J Clin Endocrinol Metab. 2004;89:4031-6.

4. Corbetta S, Bulfamante G, Cortelazzi D, Barresi V, Cetin I, Mantovani G, dkk. Adiponectin expression in human fetal tissues during midand late gestational. J Clin Endocrinol Metab. 2005;90:2397-402.

5. Kadowaki T, Yamauchi T. Adiponectin and adiponectin receptors. Endocrine Rev. 2005;26:439-51.

6. Hayman LL, Meininger JC, Daniels SR, McCrindle BW, Helden L, Ross J, dkk. Primary prevention of cardiovascular disease in nursing practice: focus on children and youth. A scientific statement from the American Heart Association Committee on atherosclerosis, hypertension, and obesity in youth of the council on cardiovascular nursing, council on epidemiology and prevention, and council on nutrition, physical activity, and metabolism. Circulation. 2007;116:344-57.

7. Yang Z, Ming XF. Recent advances in understanding endothelial dysfunction in atherosclerosis. Clin Med Res. 2006;4:53-65.

8. Bots ML, Westerink J, Rabelink TJ, de Koning JP. Assesment of flow-mediated vasodilatation (FMD) of the brachial artery: effects of technical aspects of the FMD measurement on the FMD response. Eur Heart J. 2005;26:363-8.

9. Kao YH, Mohler ER, Arger PH, Sehgal CM. Brachial artery: measurement of flow-mediated dilatation with cross-sectional US technical validation. Radiology. 2003;228: 895-900.

10. Cooke JP. Asymmetrical dimethylarginine. The uber marker? Circulation. 2004;109:1813-9.

11. Gunnarsdottir I, Birgisdottir BE, Thorsdottir I, Gudnason V, Benediktsson R. Size at birth and coronary artery disease in a population 
with high birth weight. Am J Clin Nutr. 2002; 76:1290-4.

12. Rich-Edwards JW, Kleinman K, Michels KB, Stampfer MJ, Manson JE, Rexrode KM, dkk. Longitudinal study of birth weight and adult body mass index in predicting risk of coronary heart disease and stroke in women. BMJ. 2005;330:1115-21.

13. Sachdev HPS. Low birth weight in South Asia. Int J Diab Dev Countries. 2001;21:13-27.

14. Laporan Nasional Riset Kesehatan Dasar 2007. Jakarta: Badan Penelitian dan Pengembangan Kesehatan Departemen Kesehatan Republik Indonesia; 2007.

15. Sukesi L, Sjukrudin SE, Purnomowati A, Alisyahbana B, Alisyahbana A. The association between prenatal and or postnatal growth disorder and lipid profile in adolescents aged 12-15 years old in Tanjungsari Subdistrict, Sumedang, West Java. Acta Med Indonesia J Intern Med. 2005;37:149-56.

16. Machin D, Campbell MJ. Statistical tables for the design of clinical trials. London: Blackwell Scientific Publication; 1987.

17. Cianfarani S, Martinez C, Maiorana A, Scire G,
Spadoni GL, Boemi S. Adiponectin levels are reduced in children born small for gestational age and are inversely related to postnatal catch-up growth. J Clin Endocrinol Metab. 2004;89:1346-51.

18. Leeson CPM, Kattenhorn M, Morley R, Lucas A, Deanfield JE. Impact of low birth weight and cardiovascular risk factors on endothelial function in early adult life. Circulation. 2001; 103:1264-8.

19. Bettowski J, Kedra A. Asymmetric dimethylarginine (ADMA) as a target for pharmacotherapy. Pharmacol Rep. 2006;58: 159-78.

20. Osanai T, Saitoh M, Sasaki S, Tomita H, Matsunaga T, Okumura K. Effect of shear stress on asymmetric dimethylarginine release from vascular endothelial cells. Hypertension. 2003;42:985-90.

21. Eid HMA, Lyberg T, Arnesen H, Seljeflot I. Insulin and adiponectin inhibit the TNF $\alpha$ induced ADMA accumulation in human endothelial cells: the role of DDAH. Atherosclerosis. 2007;194:e1-8. 


\title{
Aktivitas Enzim Superoksida Dismutase, Katalase, dan Glutation Peroksidase Wanita Penderita Sindrom Metabolik
}

\author{
Hery Winarsi, ${ }^{1}$ Siwi P. M. Wijayanti, ${ }^{2}$ Agus Purwanto ${ }^{3}$ \\ ${ }^{1}$ Fakultas Biologi Universitas Soedirman, ${ }^{2}$ Jurusan Kesehatan Masyarakat Fakultas Kedokteran dan \\ Ilmu-ilmu Kesehatan Universitas Soedirman, ${ }^{3}$ RSUD Margono Soekarjo Purwokerto
}

\begin{abstract}
Abstrak
Rendahnya status antioksidan endogenus memicu perkembangan kondisi sindrom metabolik (SM). Penelitian ini bertujuan untuk mengeksplorasi aktivitas enzim antioksidan superoksida dismutase (SOD), katalase, dan glutation peroksidase (GSH-PX) dalam plasma wanita penderita sindrom metabolik. Penelitian dilakukan periode MaretNovember 2010, dengan responden penelitian adalah 30 wanita yang memiliki kriteria sebagai berikut: kadar gula darah $>$ normal, body mass index $>25 \mathrm{~kg} / \mathrm{m}^{2}$, hipertrigliseridemia, high-density lipoprotein (HDL) rendah, usia $>40$ tahun, dan tinggal di Purwokerto. Seleksi responden dimulai melalui survey di poliklinik internis Rumah Sakit Umum Margono Soekarjo Purwokerto. Kepada calon responden dijelaskan tentang tujuan penelitian, kondisi SM, dan perkembangannya. Calon responden yang bersedia bergabung diminta menandatangani informed consent, diukur berat badan, tinggi badan, dan tekanan darahnya. Diambil sampel darahnya $2 \mathrm{~mL}$, intravena, ditentukan kadar glukosa darah, trigliserida, dan HDL. Bagian plasma, diuji aktivitas enzim SOD, katalase, dan GSH-PX. Data dipresentasikan sebagai rata-rata \pm standard error. Status antioksidan wanita penderita sindrom metabolik rendah, ditunjukkan oleh aktivitas SOD $379,3 \mathrm{Unit} / \mathrm{mg}$ protein, katalase 6,42 UI/mg protein, dan GSH-PX 804,9 $\mathrm{nmol} / \mathrm{g}$ protein, serta kadar malondialdehid (MDA) sebesar 2.943,4 pmol/mL. Karena itu responden perlu asupan kaya antioksidan. Simpulan, status antioksidan peroksidase sama rendah yang ditunjukkan oleh rendahnya aktivitas enzim SOD, katalase, dan glutation peroksidase. [MKB. 2012;44(1):7-12].
\end{abstract}

Kata kunci: Glutation peroksidase, katalase, sindrom metabolik, superoksida dismutase

\section{The Activity of Superoxide Dismutase, Catalase and Glutathione Peroxidase Enzymes in Metabolic Syndrome Women}

\begin{abstract}
The low endogenous antioxidant status induced development of metabolic syndrome (MetS) condition. The aim of this research was to explore superoxide dismutase (SOD), catalase (Cat), and glutathione peroxidase (GSH-PX) plasma activity on metabolic syndrome women plasma. Respondents were thirty women with blood glucose level $>$ normal, body mass index $>25 \mathrm{~kg} / \mathrm{m}^{2}$, hypertrigliceridemic, low level cholesterol-high-density lipoprotein (HDL), the age $>40$ years and live in Purwokerto. Respondents' selection was started by a survey at internist polyclinic of Margono Soekarjo General Hospital Purwokerto. They were motivated and given an explanation about aim of the research, their diseases and development risk who were willing to be respondents were asked to sign the informed consent. Then, their body weight, height and blood pressure were measured. Their blood sample of $2 \mathrm{~mL}$ were taken intravenously and tested for blood glucose, triglyceride and HDL levels. Plasma was tested for the activities of SOD, Cat and GSH-PX enzymes. Presented data was mean \pm standard error. The antioxidant status of MetS women were low, showed on the activities of SOD, catalase, and glutathione peroxidase enzyme were 379.3 Unit/ $\mathrm{mg}$ protein, $6.42 \mathrm{UI} / \mathrm{mL}, 804.9 \mathrm{nmol} / \mathrm{g}$ protein respectively, and malondialdehyde (MDA) level was $2,943.4 \mathrm{pmol} /$ $\mathrm{mL}$. Therefore, they need food enrich antioxidant. In conclusions, peroxidase antioxidant status was similar shown by low SOD, catalase and glutathione peroxidase enzyme activity, [MKB. 2012;44(1):7-12].
\end{abstract}

Key words: Catalase, glutathione peroxidase, metabolic syndrome, superoxide dismutase 